\title{
Synthesis of Some Substituted 1,3,4-Oxadiazoles from Hydrazones
}

\author{
Khalid M. Daoud, A. Kh. Ahmad Amal N. Ali \\ Chemistry Department / College of Education \\ Mosul university
}

Received
$30 / 06 / 2008$
Accepted

$15 / 10 / 2008$

\begin{abstract}
الخلاصة

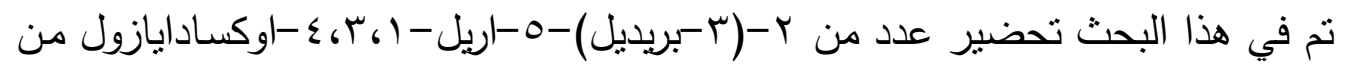

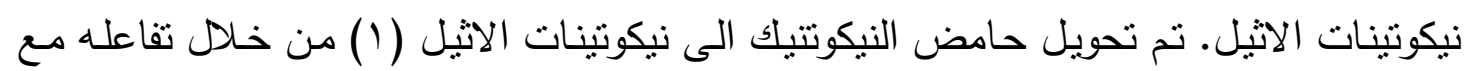

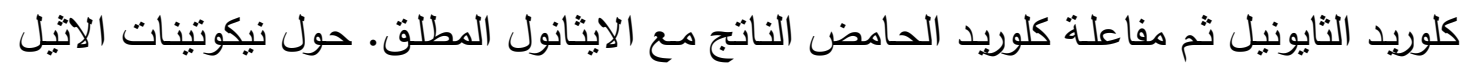

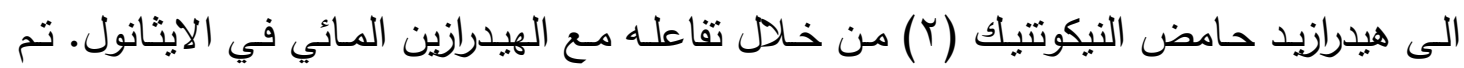

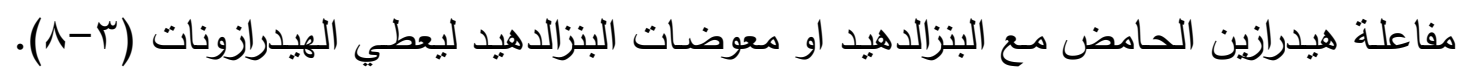

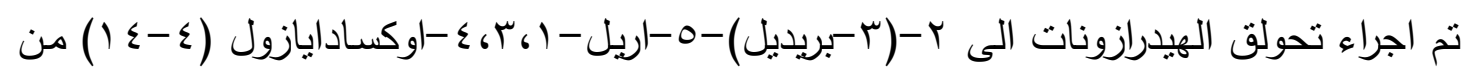
خـلال تفاعله مـع اوكسيد الرصاص. تم تشخيص تراكيب المركبات المحضرة بالطرق الفيزيائية والطيفية.
\end{abstract}

\section{ABSTRACT}

In this paper the synthesis of some 2-(3-pyridyl)-5-aryl-1,3,4oxadiazoles from hydrazones is reported. Nicotinic acid was converted to ethyl nicotinate (1) by its reaction with thionyl chloride and the resultant acid chloride was treated with absolute ethanol, the ethyl nicotinates was treated with hydrazine hydrate in ethanol to give the corresponding acid hydrazide (2). The acid hydrazide was treated with benzaldehyde or substituted benzaldehyde to give the hydrazones (3-8). The hydrazones were cyclized to 2-(3-pyridyl)-5-aryl-1,3,4-oxadiazoles (4-14) by their reaction with lead oxide.

The structure of the synthesised compounds were confirmed by physical and spectral methods. 


\section{ITRODUCTION}

Substituted 1,3,4-oxadiazoles, 1,3,4-thiadiazoles and 1,2,4-triazoles were known to posses various biological activities and other uses. 2-[3Chloro-5-(trifluromethyl)-2-pyridyloxy methyl]-5-aryl-1,3,4-oxadiazoles(1) was show activity against Leucana separate walkan $^{(1)}$, while 5-(1adimental)-1,3,4-oxadiaxole-2-thione show antivirus activities ${ }^{(2)}$. Compound (2) show broad spectrum of antiinflammatory activity ${ }^{(3)}$.<smiles>FC(F)(F)c1cnc(OCc2nnc([Al])o2)c(Cl)c1</smiles><smiles>[R]c1ccc(Nc2nnc(C([2H])Oc3ccc(NC(C)=O)cc3)o2)cc1</smiles>

In industrial field 2,5-Bis(4-dimethylamino phenyl)-1,3,4oxadiazole act as corrosion inhibitors ${ }^{(4)}$.

The synthesis of 1,3,-oxadiazoles were achieved from hydrazide by its reaction with carbon disulfide in pyridine ${ }^{(5)}$ or ethanolic potassium hydroxide ${ }^{(6)}$. Compound (3) was synthesized from the reaction hydrazide with carbon disulfide in ethanolic potassium hydroxide ${ }^{(7)}$.

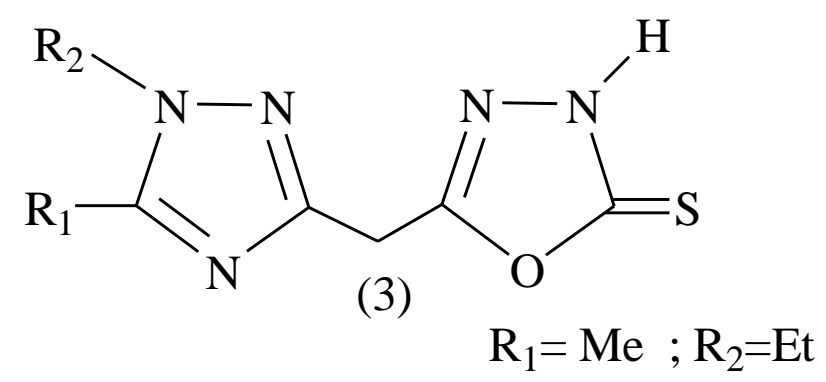

The oxidation of substituted thiosemicarbazides with various reagents such as lead oxide ${ }^{(8)}$, mercuric acetate ${ }^{(9)}$ and iodine/potassium iodine $^{(10)}$ afforded substituted 1,3,4-oxadiazoles. The hydrazides were converted to substituted 1,3,4-oxadiazoles by their reaction with carboxylic acid in presence of phosphorus oxychloride ${ }^{(11)}$. Substituted 1,3,4-oxadiazole were synthesized by many research workers due to their biological importance such as antibacterial ${ }^{(12)}$, anticancer ${ }^{(13)}$ as compound (4), and anti-inflammatory ${ }^{(14)}$. 
<smiles>CC1=NN2C(=NCC(C)=C2C(=O)NC=[In])S1</smiles>

1,3,4-Thiadiazoles and 1,2,4-triazoles are related to 1,3,4oxadiazoles in a way that there five membered ring compounds containing three heteroatoms.

Substituted 1,3,4-thiadiazoles were synthesized from thiosemicarbazide by its reaction with carboxylic acid in presence of sulfuric $\operatorname{acid}^{(15)}$, substituted thiosemicarbazide were cyclized with concentrated sulfuric acid ${ }^{(16,17)}$ or phosphoric acid $^{(18)}$ to substituted 1,3,4thiadiazoles.

1,2,4-Triazole compounds act as anticancer ${ }^{(19)}$, antifungal, antibacterial $^{(20)}$ and plant growth regulator ${ }^{(21)}$ as compound (5).<smiles>CCNC(=S)SC(Cn1cncn1)C(C)(C)C</smiles>

(5)

Substituted 1,2,4-triazoles were synthesized from thiosemcarbazide by their reaction with aqueous sodium hydroxide ${ }^{(22)}$ or from hydrazides by their reaction with imidine in ethanol ${ }^{(23)}$ as compound (6).<smiles>[R]c1cc([R])c(N)c(-c2nc([R])n[nH]2)c1</smiles>
reported.

In this paper the synthesis of some substituted 1,3,4-oxadiazoles is

\section{EXPPERIMENTAL}

Melting points were determined using kofler hot plate and were uncorrected. IR spectra were recorded using $\mathrm{KBr}$ on Infrared spectrophotometer Model Tensor 27, Bruker Co., UV spectra were 
recorded on Schimadzu UV-160, UV-Visible Recording Spectrophotometer. ${ }^{1} \mathrm{H}$ NMR spectra were recorded in (DMSO) on spectrometer Bruker Ac 300 (300 MHz proton) (France).

\section{Ethyl nicotinate (1) $\square$ \\ Method-A}

Thionyl chloride $(13.0 \mathrm{ml}, 0.41 \mathrm{~mole})$ was added dropwise with cooling and stirring to nicotinic acid (5.1 g, 0.41 mole), the mixture was refluxed for $(2 \mathrm{hr}$.) on water. The excess thionyl chloride was evaporated under vacuum.

Dry benzene $(20 \mathrm{ml})$ and absolute ethanol $(6 \mathrm{ml})$ were added with cooling over a period of (10 min.), the mixture was refluxed for $(2 \mathrm{hr}$.), after cooling the mixture to room temperature, the media was neutralized with $20 \%$ sodium bicarbonate. The organic layer was separated, and the aqueous layer extracted with ether $(2 \times 25 \mathrm{ml})$, the combined organic layer, dried and evaporated under reduced pressure, the colorless oily product (5 g) b.p. $(223-225)^{\circ} \mathrm{C}$, lit ${ }^{(24)}(223-224)^{\circ} \mathrm{C}$, yield $64 \%$.

\section{Method B}

A mixture of nicotinic acid $(6.2 \mathrm{~g}, 0.05$ mole) absolute ethanol (30 $\mathrm{ml})$, and concentrated sulfuric acid $(2 \mathrm{ml})$ was refluxed for $(4 \mathrm{hr}$.) the mixture was cooled and added with stirring to crushed ice (100 g), concentrated ammonium hydroxide solution was added to obtained weakly basic solution. The product was extracted with ether $(3 \times 15 \mathrm{ml})$ the ether layer dried and evaporated under reduced pressure.

\section{Nicotinic acid hydrazide (2)}

A mixture of ester (1) (1.5 g. 0.01 mole), and hydrazine hydrate (2.4 ml, 0.05 mole) in absolute ethanol $(50 \mathrm{ml})$ was refluxed for $(12 \mathrm{hr}$.). The hydrazide was precipitated on cooling, filtered and recrystallized from ethanol m.p. $(168-170){ }^{\circ} \mathrm{C}$, lit $^{(25)}(161-162)^{\circ} \mathrm{C}$, yield $80 \%$.

\section{The hydrazones (3-8)}

The hydrazide (2) (1.5 g, 0.01 mole) was mixed with ethanol (50 $\mathrm{ml})$ and to this solution benzaldehyde or substituted benzaldehyde (0.01 mole) in ethanol $(25 \mathrm{ml})$ was added. The reaction mixture was refluxed for $(2 \mathrm{hr}$.) then was cooled, the precipitate was filtered and recrystallized from ethanol.

\section{2-(3-Pyridyl)-5-aryl-1,3,4-oxadiazoles (9-14).}

One of the hydrazones (1-6) (0.01 mole) was added to glacial acetic acid $(40 \mathrm{ml})$ with stirring, lead dioxide $(2.4 \mathrm{~g}, 0.01$ mole $)$ was added to the homogenous solution. The mixture was stirred at $25^{\circ} \mathrm{C}$ for $(1 \mathrm{hr}$.), ice-water was added $(100 \mathrm{ml})$ and the mixture left to stand for $(24$ hr.) in fridge the precipitate was filtered and recrystallized from ethanol. 


\section{RESULTS AND DISCUSSION}

In this paper the synthesis of some substituted 1,3,4-oxadiazoles were synthesized from hydrazones. Nicotinic acid was converted to ethanol nicotinate (1) by its reaction with thionyl chloride to give the acid chloride which was treated with absolute ethanol to give ester (1) as colorless oil. The ester (1) was synthesized from by second method from nicotinic acid, concentrated sulfuric acid and absolute ethanol both methods gave satisfactory yield. The ester (1) was treated with hydrazine hydrate in ethanol to give hydrazide (2) m.p. $(168-170)^{\circ} \mathrm{C}$. The acid hydrazide was converted to the corresponding hydrazones (3-8) by their reaction with benzaldehyhde or substituted benzaldehyde in ethanol, IR spectra of the hydrazones shows $v_{c m}^{-1}$ 3204-3140 (N-H). 1675-1665 $(\mathrm{C}=\mathrm{O}), 1620-1600(\mathrm{C}=\mathrm{N})$; compound (4) show absorption at $3450 \mathrm{~cm}^{-1}$ $(\mathrm{OH})$ and compound (6) show absorption $\mathrm{vcm}^{-1}$ at 1525 and $1310\left(\mathrm{NO}_{2}\right)$. The hydrazones were cyclized to 2-(3-pyridyl-5-aryl-1,3,4-oxadiazole (914) by their reaction with lead oxide. The IR spectra of the hydrazones show $\mathrm{vcm}^{-1}$ at 643-1604 $(\mathrm{C}=\mathrm{N}), 1142-110(\mathrm{C}-\mathrm{O}-\mathrm{C})$, while compound $(10)$ show $\mathrm{vcm}^{-1}$ at $3455(\mathrm{OH})$ and compound (12) $\mathrm{vcm}^{-1}$ at 1512 and 1310 $\left(\mathrm{NO}_{2}\right)$ Tables (3 and 4). The NMR spectrum of compounds (7) shows sppm 8.3-8.7 multiplet, for $4 \mathrm{H}$ pyridine; 9.2, singlet for $1 \mathrm{H}$, amide proton; 7.0-7.5 multiplet, for $4 \mathrm{H}$ aromatic proton and 3.5 singlet for $3 \mathrm{H}$ methoxy protons while compound (8) show NMR spectrum at $\delta 8.8$ singlet for amide proton, 7.3-7.5 multiplet for aromatic proton, 7.1 singlet for $1 \mathrm{H}$ $(\mathrm{N}=\mathrm{CH}), 7.9-8.4$ multiplet for pyridine ring protons and 3.4, singlet for methoxy group. Table (5).

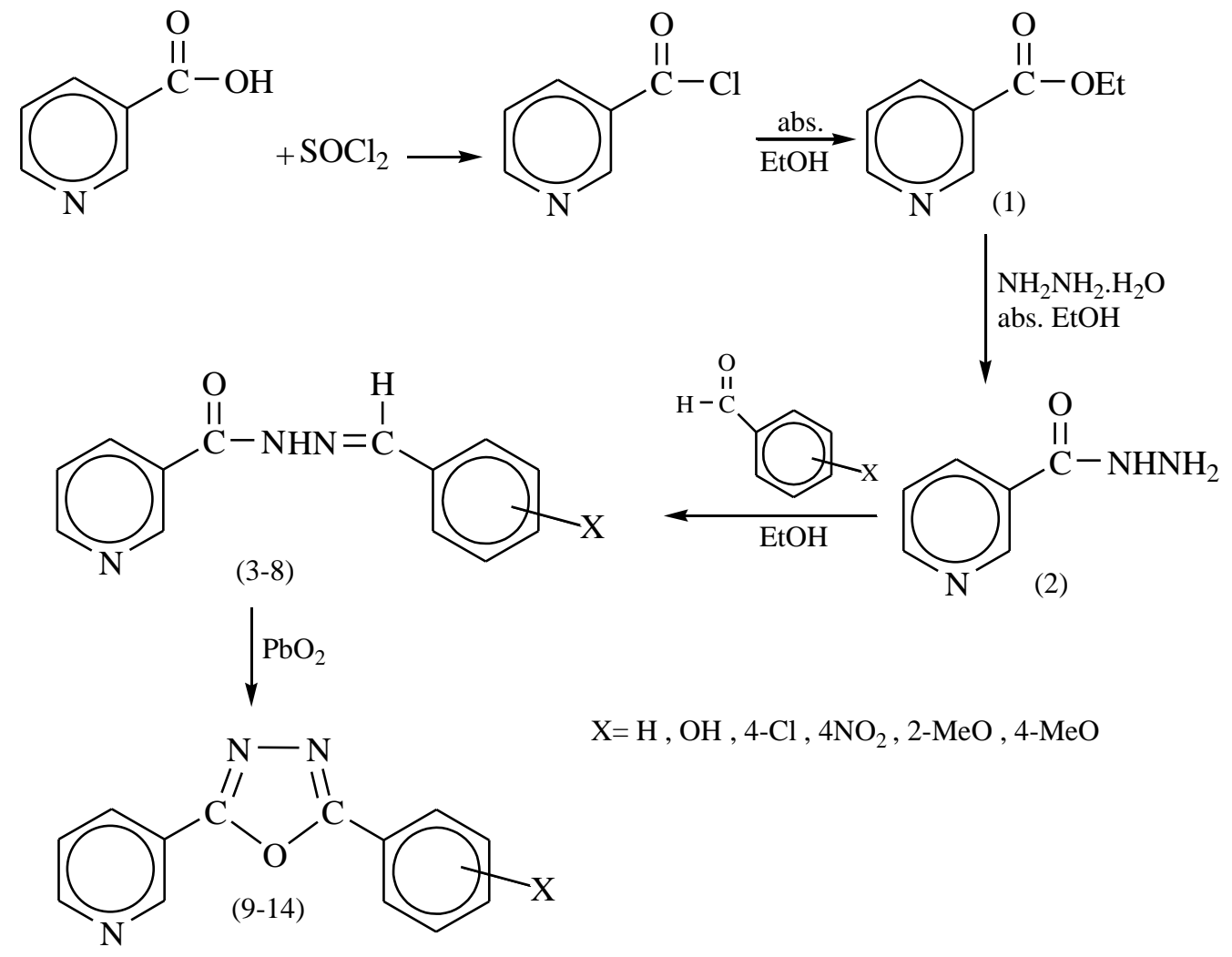

Scheme (1) 
Synthesis of Some Substituted 1,3,4-Oxadiazoles from Hydrazones.

Table (1): Physical data of hydrazones (3-8)

\begin{tabular}{|c|c|c|c|c|}
\hline Compound & $\mathrm{X}$ & $\begin{array}{c}\text { Molecular } \\
\text { formula }\end{array}$ & m.p. ${ }^{\circ} \mathrm{C}$ & \% yelid \\
\hline 3 & $\mathrm{H}$ & $\mathrm{C}_{13} \mathrm{H}_{10} \mathrm{~N}_{3} \mathrm{O}$ & $142-143$ & 86 \\
\hline 4 & $2-\mathrm{OH}$ & $\mathrm{C}_{13} \mathrm{H}_{10} \mathrm{~N}_{3} \mathrm{O}_{2}$ & $186-188$ & 80 \\
\hline 5 & $4-\mathrm{Cl}$ & $\mathrm{C}_{13} \mathrm{H}_{9} \mathrm{ClN}_{3} \mathrm{O}$ & $178-180$ & 75 \\
\hline 6 & $4-\mathrm{NO}_{2}$ & $\mathrm{C}_{13} \mathrm{H}_{9} \mathrm{~N}_{4} \mathrm{O}_{3}$ & $234-236$ & 83 \\
\hline 7 & $2-\mathrm{OCH}_{3}$ & $\mathrm{C}_{14} \mathrm{H}_{12} \mathrm{~N}_{3} \mathrm{O}_{2}$ & $228-230$ & 80 \\
\hline 8 & $4-\mathrm{OCH}_{3}$ & $\mathrm{C}_{14} \mathrm{H}_{12} \mathrm{~N}_{3} \mathrm{O}_{2}$ & $144-146$ & 75 \\
\hline
\end{tabular}

Table (2): Physical data of substituted 1,3,4-oxadiazoles (9-14)

\begin{tabular}{|c|c|c|c|c|}
\hline Compound & $\mathrm{X}$ & $\begin{array}{c}\text { Molecular } \\
\text { formula }\end{array}$ & m.p. ${ }^{\circ} \mathrm{C}$ & \% yelid \\
\hline 9 & $\mathrm{H}$ & $\mathrm{C}_{13} \mathrm{H}_{9} \mathrm{~N}_{3} \mathrm{O}$ & $105-106$ & 65 \\
\hline 10 & $2-\mathrm{OH}$ & $\mathrm{C}_{13} \mathrm{H}_{9} \mathrm{~N}_{3} \mathrm{O}_{2}$ & $160-162$ & 71 \\
\hline 11 & $4-\mathrm{Cl}$ & $\mathrm{C}_{13} \mathrm{H}_{8} \mathrm{ClN}_{3} \mathrm{O}$ & $141-143$ & 75 \\
\hline 12 & $4-\mathrm{NO}_{2}$ & $\mathrm{C}_{13} \mathrm{H}_{8} \mathrm{~N}_{4} \mathrm{O}_{3}$ & $180-182$ & 60 \\
\hline 13 & $2-\mathrm{OCH}_{3}$ & $\mathrm{C}_{14} \mathrm{H}_{11} \mathrm{~N}_{3} \mathrm{O}_{2}$ & $191-193$ & 55 \\
\hline 14 & $4-\mathrm{OCH}_{3}$ & $\mathrm{C}_{14} \mathrm{H}_{11} \mathrm{~N}_{3} \mathrm{O}_{2}$ & $113-115$ & 75 \\
\hline
\end{tabular}

Table (3): IR and UV spectral data of hydrazones (3-8)

\begin{tabular}{|c|c|c|c|c|c|c|}
\hline \multirow{2}{*}{ Compound } & \multirow{2}{*}{$\mathrm{X}$} & \multicolumn{4}{|c|}{$\mathrm{IR} v \mathrm{~cm}^{-1} \mathrm{KBr}$} & \multirow{2}{*}{$\begin{array}{c}\mathrm{UV}(\mathrm{EtOH}) \\
\lambda_{\max }\end{array}$} \\
\hline & & $\mathrm{N}-\mathrm{H}$ & $\mathrm{C}=\mathrm{O}$ & $\mathrm{C}=\mathrm{N}$ & Others & \\
\hline 3 & $\mathrm{H}$ & 3140 & 1665 & 1605 & & 334 \\
\hline 4 & $2-\mathrm{OH}$ & 3200 & 1670 & 1620 & $3450(\mathrm{OH})$ & 315 \\
\hline 5 & 4-Cl & 3204 & 1667 & 1610 & & 300 \\
\hline 6 & $4-\mathrm{NO}_{2}$ & 3170 & 1675 & 1600 & $\begin{array}{c}1525 \\
1310\left(\mathrm{NO}_{2}\right)\end{array}$ & 324 \\
\hline 7 & $2-\mathrm{OCH}_{3}$ & 3200 & 1668 & 1603 & & 330 \\
\hline 8 & $4-\mathrm{OCH}_{3}$ & 3180 & 1666 & 1601 & & 322 \\
\hline
\end{tabular}

Table (4): IR and UV spectral data of hydrazones (9-14)

\begin{tabular}{|c|c|c|c|c|c|}
\hline \multirow{2}{*}{ Compound } & \multirow{2}{*}{$\mathrm{X}$} & \multicolumn{3}{|c|}{$\mathrm{IR} \mathrm{vcm}^{-1} \mathrm{KBr}$} & $\mathrm{UV}(\mathrm{EtOH})$ \\
\cline { 3 - 6 } & & $\mathrm{C}=\mathrm{N}$ & $\mathrm{C}-\mathrm{O}-\mathrm{C}$ & Others & $\lambda_{\max }$ \\
\hline 9 & $\mathrm{H}$ & 1630 & 1122 & & 310 \\
\hline 10 & $2-\mathrm{OH}$ & 1643 & 1100 & $3455(\mathrm{OH})$ & 300 \\
\hline 11 & $4-\mathrm{Cl}$ & 1610 & 1142 & & 240 \\
\hline 12 & $4-\mathrm{NO}_{2}$ & 1617 & 1107 & 1512 & 318 \\
\hline 13 & $2-\mathrm{OCH}_{3}$ & 1604 & 1112 & & 305 \\
\hline 14 & $4-\mathrm{OCH}_{3}$ & 1625 & 1134 & & 295 \\
\hline
\end{tabular}


Table (5): The ${ }^{1}$ H NMR spectral data for compound (7 and 8 ).

\begin{tabular}{|c|ll|}
\hline Compound No. & \multicolumn{1}{c|}{$\delta, p p m(\mathrm{DMSO})$} \\
\hline & 9.2 & $(\mathrm{~S}, 1 \mathrm{H}, \mathrm{CONHN})$ \\
7 & $8.3-8.7$ & $(\mathrm{~m}, 4 \mathrm{H}, \mathrm{Pyridine}-\mathrm{H})$ \\
& $7-7.5$ & $(\mathrm{~m}, 4 \mathrm{H}, \mathrm{Ar}-\mathrm{H})$ \\
& 6.9 & $(\mathrm{~S}, 1 \mathrm{H}, \mathrm{N}=\mathrm{CH})$ \\
& 3.5 & $(\mathrm{~S}, 3 \mathrm{H}, \mathrm{OCH})$ \\
\hline & 8.8 & $(\mathrm{~S}, 1 \mathrm{H}, \mathrm{CONHN})$ \\
& $7.9-8.4$ & $(\mathrm{~m}, 4 \mathrm{H}, \mathrm{Pyridine}-\mathrm{H})$ \\
& $7.3-7.5$ & $(\mathrm{~m}, 4 \mathrm{H}, \mathrm{Ar}-\mathrm{H})$ \\
& 7.1 & $(\mathrm{~S}, 1 \mathrm{H}, \mathrm{N}=\mathrm{CH})$ \\
& 3.4 & $(\mathrm{~S}, 3 \mathrm{H}, \mathrm{OCH})$ \\
\hline
\end{tabular}

\section{REFFERENCES}

1. Cao S.; Qian X.; Song G. and Huang Q., J. Fluorine chem., 117, 63. (2002).

2. El-Eman A. A.; Al-Deeb O. A.; Alomar M. and Lenmam J., Bioorg, Med, Chem. 12, 5107. (2004).

3. Nargund L. V.; Reddy G. R. and Hariprasad, J. Pharm. Sci., 83,2,246. (1994) .

4. Bentiss F.; Traisenel M.; Vejin H.; Hildeber H. F. and Lagrnee M., Corrosion Sci., 46, 2781. (2004) .

5. Hoggarth E., J. Chem. Soc., 1163. (1952) .

6. Maslat A. O.; Abussad M.; Tashtoush H. and Al-Talib M., Pol. J. Pharmacol., 54, 55. (2002).

7. Al-Soud Y. A.; Al-Dweri M. N. and Al-Masoudi N. A., iL Farmao., 285. (2004).

8. Brooks J. D.; Charlton P.T.; Macey P. E.; Peak D. A. and Short W. F., J. Chem. Soc., Part 1, 542. (1950).

9. Zon X. J.; Hualai L.; Jin G. Y. and Zhang Z. X. J. Agric. Food Chem., Vol. 50, 3757. (2002).

10. Amir A. and Shikla, J. Europ. Med. Chem., 39, 535. (2004).

11. El-Tamaty E. H.; Abdel-Fattah M. E. and El-Deen I. M., Indian Journal of chemistry, Vol. 35 B, 1067. (1996). 
12. Thomasco L. M.; Gadwood R. C.; Weaver E. A.; Occhooda J. M.; Ford C. W.; Zuren G. E.; Hamel J. C.; Stapert D.; Moerman J. K.; Shaadt R. D. and Yagi B. H., Bioorg. Med. Hem. Let., 13, 4193. (2003).

13. Terziogluard N. and Gursoy A., Eur. J. Med. Chem., 38, 781. (2003).

14. Khan K.; Zia-Ullah; Roni M.; Perveen S.; Haider S. M.; Choudhany M. I.; Rehmn A. and Velter U., Letter. Org. Chem., 1, 50. (2004).

15. Potts K. T. and Huseby R. MJ. Org. Chem., 31, 9, 3528., (1966).

16. Simiti I.; Muresan A.; Pop R.D. and Chiorean V., Rev. Roum. Biochim, 9, 18. (1982).

17. Zamami K.; Faghihi K. and Mehranijani M. S., Pol. J. Pharmacol., 55, 1111. (2003).

18. Varraresou A.; Siatra P. T.; Dalla T. A. and Tsantili K., 1L Farmaco., 53, 320. (1998).

19. Holla B. S., Veerendra B., Shivanande M. K. and Poojary B., European Med. Chem., 38, 759. (2003).

20. Collin X.; Saulean A. and Goulon J., Bioorg. Med. Chem., Let., 13, 2601. (2003).

21. Liang-Zhong X.; Fang-Fang J.; Jian-Gang S.; Ping-Ping S. and Kui J., Chinese J. Chem., 22, 698. (2001).

22. Labanauskas L.; Udrenaite E.; Gaidelic P. and Brukstus A., 1L Farmmco., 59, 255. (2004).

23. Shverkhgeimer M. G. A., Chemistry of Heterocyclic compound, Vol. 27, No. 4, 387. (2001).

24. A. I. Vogel ,Practical Organic Chemistry Including Qualitative Organic Analysis" , $3^{\text {rd }}$, Ed., Longmans, P.899. (1985).

25. Dictionary of organic compounds, $5^{\text {th }} \mathrm{Ed}$, Chapman and Hall Mack printing company, Vol. 5, P. 4846. (1982). 